\title{
Wpływ pestycydów na zdrowie człowieka
}

\section{Effect of pesticides on human health}

\author{
Marta Grotowska, Katarzyna Janda ${ }^{\bowtie}$, Karolina Jakubczyk
}

Pomorski Uniwersytet Medyczny w Szczecinie, Zakład Biochemii i Żywienia Człowieka, ul. Broniewskiego 24, 71-460 Szczecin Pomeranian Medical University in Szczecin, Department of Biochemistry and Human Nutrition

$\triangle$ kjanda@pum.edu.pl

\begin{abstract}
Pesticides are a large group of biologically active chemicals used in plant protection. There are zoocides that work against pests, herbicides for weed control, bacteriocides against bacteria, and fungicides that eliminate moulds. The use of pesticides in agriculture across the world is increasing with industrial, scientific and technical progress. Despite the effectiveness of these compounds in plant protection, interest in the side effects and health consequences of pesticide use is growing.

This paper reports on the negative impact of pesticides on the human body, particularly the development of tumours in adults, and the impact of pesticides on the foetus and pregnant women.
\end{abstract}

The presence of pesticides in the environment is associated with the occurrence of miscarriages in women, premature births, neural tube defects in children or delay in their development. Another problem discussed in this paper is the presence of pesticide residues in food, and intoxication with various compounds from this group. Attention is also drawn to alternative products - biopesticides.

The aim of this paper is to show how the use of pesticides in agriculture affects the human body, and what health consequences it entails. The work is a review of the latest scientific publications on pesticides.

Keywords: pesticides; health; glyphosate; human; environment.

\begin{abstract}
ABSTRAKT
Pestycydy to szeroka grupa obejmująca substancje chemiczne biologicznie czynne stosowane w środkach ochrony roślin. Wyróżnia się m.in: zoocydy, których zadaniem jest przeciwdziałanie szkodnikom zwierzęcym, herbicydy do zwalczania chwastów, bakteriocydy zwalczające bakterie oraz fungicydy eliminujące grzyby mikroskopowe. Wraz z rozwojem przemysłowym, a także naukowo-technicznym, wzrasta wykorzystanie pestycydów w rolnictwie na całym świecie. Pomimo skuteczności tych związków w ochronie roślin wciąż duże jest zainteresowanie skutkami ubocznymi i konsekwencjami zdrowotnymi stosowania pestycydów.

W pracy przedstawiono doniesienia o negatywnym wpływie pestycydów na organizm ludzki, w szczególności powstawanie
\end{abstract}

nowotworów u dorosłych, wpływ na płód oraz kobiety ciężarne. Wykazano, że obecność pestycydów w środowisku ma związek $\mathrm{z}$ występowaniem poronień u kobiet, przedwczesnych porodów, wad cewy nerwowej u dzieci czy opóźnień w ich rozwoju. Kolejnym problemem omówionym w niniejszej pracy jest występowanie pozostałości pestycydów w żywności oraz zatrucia różnymi związkami należącymi do tej grupy. Zwrócono również uwagę na produkty alternatywne, czyli biopestycydy.

Celem pracy było przedstawienie wpływu na organizm ludzki wykorzystywania pestycydów w rolnictwie. Praca jest przeglądem najnowszych publikacji naukowych dotyczących pestycydów. Słowa kluczowe: pestycydy; zdrowie; glifosat; człowiek; środowisko.

\section{WSTĘP}

Polska należy do krajów, w których ponad 60\% powierzchni użytkowej zajmują pola uprawne. Wykorzystanie pestycydów w rolnictwie rośnie wraz z przybywaniem ludności na świecie oraz postępem przemysłowym, a także naukowo-technicznym. Dzieje się tak, ponieważ poszukuje się sposobów na zwiększenie wydajności upraw oraz zmniejszenie ich strat poprzez np. wyeliminowanie chorób roślin lub ograniczenie populacji owadów ży wiących się tymi roślinami. Pestycydy są rozwiązaniem dla rolników walczących z takimi właśnie problemami. Według badań Światowej Organizacji Zdrowia (WHO)/FAO na przełomie lat 80--90. XX w. całościowe straty w rolnictwie w ciągu roku wynosiły więcej niż 30\%, w tym 15\% spowodowanych było szkodnikami, zaś $11 \%$ - chorobami roślin. Należy jednak pamiętać, że mimo licznych zalet stosowania pestycydów kluczowym problemem jest ich niekorzystny wpływ na zdrowie.

\section{PESTYCYDY - DEFINICJA, NAZWA, DZIAŁANIE}

Pestycyd, wg Sikorskiej i Wędzisz [1], to substancja chemiczna biologicznie czynna stosowana w środkach ochrony roślin. Pestycydy stanową grupę związków naturalnych lub syntetycznych. Nazwa wywodzi się z łaciny i oznacza pestis - szkodnik, zaraza i cedeo - niszczyć (ceadere - zabijać) [1]. Z kolei Dobosz i Jaskólecki [2] rozszerzają pojęcie tak, że definicja ta obejmuje też wszelkie substancje, których zadaniem jest regulowanie 
wzrostu roślin lub owadów. W odniesieniu do pestycydów stosuję się również inne nazwy, np. środki przeciwpasożytnicze, szkodnikobójcze lub zwyczajnie środki ochrony roślin [2]. Teoretycznie ich działanie powinno obejmować wysoką toksyczność dla szkodników, natomiast niską dla innych organizmów, zwłaszcza tych pożytecznych, a w tym przede wszystkim dla człowieka oraz środowiska [2]. Wrzosek i wsp. [3] uważają, iż na szczególną uwagę zasługuje problem ochrony wód przed zanieczyszczeniami pestycydowymi. Występowanie środków ochrony roślin stwierdzono we wszystkich rodzajach wód krążących w ekosystemie. Idealny pestycyd powinien nie kumulować się, być biologicznie i środowiskowo nieszkodliwy oraz mieć cechy krótkiej trwałości w ekosystemie [3]. Jednak w praktyce jest zupełnie inaczej. Rzeszutek i wsp. [4] twierdzą, że właśnie dlatego wprowadzono tzw. okres karencji, jaki musi minąć między ostatnią użytą dawką określonego pestycydu a zbiorem plonu [4]. Każdy środek działa w inny sposób, w zależności od rodzaju danego zagrożenia dla uprawy. Wyróżnia się głównie: zoocydy (w tym larwicydy oraz owicydy) - których zadaniem jest przeciwdziałanie szkodnikom zwierzęcym, herbicydy - do zwalczania chwastów, bakteriocydy - zwalczające bakterie oraz fungicydy - do eliminacji grzybów pleśniowych. Klasyfikacja może być dokonana również na podstawie budowy chemicznej na środki nieorganiczne i organiczne [3]. Działanie pestycydów można również podzielić na powierzchniowe i układowe. To pierwsze ma za zadanie ochronić roślinę głównie z zewnątrz - pestycyd wchłania się bezpośrednio przez skórę owada, dostając się do całego jego organizmu, natomiast drugi typ działa układowo, tzn. jest rozprowadzany po całej roślinie, wnika także do wewnątrz i dzięki temu może unieszkodliwić szkodniki lub inne pasożyty zarówno od środka, jak i na powierzchni [1].

\section{KLASYFIKACJA I PODZIAt}

Podział pestycydów wynika z rodzaju szkodnika, na którego dany preparat ma działać. Ten podział można jeszcze nieco poszerzyć. Z zoocydów wyróżnia się aż 8 podgrup, a mianowicie: insektycydy (owadobójcze), akarycydy (przeciw roztoczom), nematocydy (przeciw nicieniom), aficydy (unieszkodliwiające mszyce), moluskocydy (zwalczające ślimaki), rodentycydy (przeciw gryzoniom), atraktanty - środki zwabiające oraz repelenty - odstraszające. Osobną grupę stanowią fungicydy, czyli środki zwalczające grzyby strzępkowe. Z kolei herbicydy dzielą się dodatkowo na 3 podgrupy, w zależności od działania [3]. Są to wg Wrzosek i wsp. [3]: totalne (niszczące całą populację roślin), wybiórcze (eliminujące określone gatunki roślin) oraz regulatory wzrostu, do których zaliczane są zarówno inhibitory, jak i stymulatory. Jednak istnieje jeszcze jeden podział, mianowicie ze względu na klasy - chodzi tutaj głównie o to, jakie substancje chemiczne zawiera dany pestycyd.

Pestycydy choloorganiczne w większości zostały zakazane lub ograniczone ze względu na wysoką toksyczność dla gatunków niecelowanych, w tym także dla ludzi. Mają długą trwałość w środowisku, słabo ulegają procesom biodegradacji, co skutkuje długim zanieczyszczaniem ekosystemu. Najczęściej spotykane to: dieldryna, chlordan, DDT, DDE, $\beta$-heksachlorocykloheksan, tetrachlorek węgla, heptachlor, $\gamma$-heksachlorocykloheksan (lindan). Wszystkie są zakazane w Unii Europejskiej (UE).

Pestycydy fosforoorganiczne zostały odkryte w trakcie II wojny światowej, w związku z badaniami nad bronią chemiczną. Hamują aktywność acetylocholinoesterazy - jednego z ważniejszych enzymów dla obwodowego i ośrodkowego układu nerwowego [5]. Greenpeace [5] opisuje, że proces ten zachodzi również w organizmach, przeciwko którym dany środek nie był stosowany. Spotykane substancje to m.in.: kumafos, fosmet, acefat, paration metylowy, chloropiryfos, diazinon, fonofos, dichlorfos. Według Greenpeace [5] chloropiryfos i malation są obecnie zatwierdzone do użycia w UE, zaś w USA są zakazane na obszarach zamieszkałych przez ludzi. Karbaminiany wykazują podobne działanie do pestycydów fosforoorganicznych - również powodują zakłócenia acetylocholinoesterazy. Należą do grupy substancji organicznych. Greenpeace [5] sugeruje, że niektóre z nich mają niekorzystny wpływ na rozwój człowieka zarówno w okresie niemowlęcym, jak i później. Najczęściej spotykane to ditiokarbaminiany (mankozeb i maneb), metiokarb, aldikarb, pirymikarb, karbaryl, EPTC. W krajach UE dozwolone są mankozeb, maneb, metiokarb i primikarb.

Kolejna grupa to syntetyczne pyretroidy, które upośledzają gospodarkę hormonalną, a także zakłócają przesyłanie sygnałów między komórkami, blokując kanały jonowe [5]. Niektóre z nich mogą powodować bezpłodność u mężczyzn. Najczęściej spotykane to cyhalotryna, permetryna, cypermetryna, deltametryna. Dwie ostatnie są dopuszczone do użycia w UE. Neonikotynoidy, w swoim działaniu i budowie przypominające nikotynę, blokują niektóre szlaki sygnalizacyjne komórek i zaburzają pracę układu nerwowego człowieka. Główne substancje to imidakloprid, klotianidyna, tiametoksam. Chloroacetamidy wpływają na powstawanie wad rozwojowych, a toalachlor i metachlor - główni przedstawiciele tej grupy są obecnie niedozwolone w krajach UE.

Do osobnej grupy można zaliczyć pestycydy, które nie zostały zakwalifikowane do żadnej z powyższych grup. Przykładem jest parakwat, wg Greenpeace [5] neurotoksyczny, hamujący fotosyntezę, zakazany w UE. Do grupy tej należy również glifosat, jednak na jego temat jest wiele kwestii spornych dotyczących wpływu na organizm ludzki. W 2015 r. Międzynarodowa Agencja Badania Raka stwierdziła, że może być substancją rakotwórczą. Potwierdzeniem miały być liczne badania na zwierzętach oraz dowody naukowe wykazujące związek między glifosatem a zachorowalnością na rzadką odmianę nowotworu - ziarnicę złośliwą [5].

\section{PRODUKTY NAJCZĘŚCIEJ SKAŻONE POZOSTAŁOŚCIAMI PESTYCYDÓW}

Pestycydy powszechnie występują w otoczeniu człowieka; pozostałości możemy znaleźć zarówno w glebie, jak i roślinach, które spożywamy. Mają też znaczący wpływ na królestwo 
zwierząt. Według badań Komisji Europejskiej surowcem, w którym najczęściej stwierdzano pozostałości pestycydów, był szpinak. Jednak to nie jedyny produkt, przez który jesteśmy narażeni na ich spożywanie [2]. Dobosz i Jaskólecki [2] wykonali badania na produktach najczęściej spożywanych, tj. truskawkach, soku z czarnej porzeczki oraz papryce pomarańczowej. Obszarem badanym było województwo śląskie, zaś produkty pochodziły z wielkich spożywczych przedsiębiorstw. W badanych truskawkach wyizolowano pozostałości 21 pestycydów, zaś z papryki i soku z czarnej porzeczki - po 20. Najczęstszymi były pestycydy fosforoorganiczne, które stanowiły aż 50\% wszystkich wykrytych pestycydów. Jednak ich stężenia nie przekraczały dopuszczalnych norm. Spożywając te produkty, nie jesteśmy narażeni na zatrucie pestycydami, co nie oznacza jednak, że nie wyrządzają one szkód w naszym organizmie, gdy spożywamy je przez kilka, kilkanaście lub nawet kilkadziesiąt lat [2]. W 2013 r. Pesticide Action Network Europe (PAN Europe) opublikował listę 10 najbardziej skażonych pestycydami produktów. Pierwsze miejsce zajmuje sałata, następnie pomidor i ogórek, z czego pomidor jest najczęściej i najchętniej konsumowanym produktem na rynku, zwłaszcza w okresie letnim. Dalej klasyfikują się: jabłka, por, nektarynki, truskawki, gruszki, winogrona zielone oraz żółta papryka [6], co potwierdzają Dobosz i Jaskólecki, ponieważ badane produkty znalazły się w rankingu PAN Europe [2, 6].

\section{WPŁYW NA ROZWÓJ NOWOTWORÓW U DOROSEYCH}

W 1993 r. rozpoczęto wieloletnie badania, których celem była kontrola osób pracujących w rolnictwie, mających styczność z pestycydami oraz ocena potencjalnych skutków zdrowotnych, głównie nowotworowych, wywołanych przez kontakt z nimi. Dotyczyło to zarówno samych rolników, jak i osób rozpylających pestycydy na polach [5]. Greenpeace opisuje, że narażenie zawodowe na 12 różnych rodzajów pestycydów da się powiązać ze zwiększonym ryzykiem rozwoju wszystkich nowotworów [5].

Pestycydy mają wpływ na powstawanie nowotworów poprzez działanie na metylację DNA, co prowadzi do zmiany ekspresji genów. Rzeszutek i wsp. [4] przytoczyli badania, w których wykonywano eksperyment na myszach. Udowodnili, że w wyizolowanym z plemników DNA doszło do 68 zmian metylacji DNA w porównaniu z wzorcem kontrolnym. W dalszej analizie zaobserwowano aż 75\% wzrost zachorowań na jeden z nowotworów - prostaty, jąder bądź nerek [4]. Z kolei Rzeszutek i wsp. [4] twierdzą, że $34 \%$ badanej populacji zapadło na dwie lub więcej dolegliwości w porównaniu z grupą kontrolną. Takie działanie przypisano fungicydowi - winklozolinie. W rolnictwie często stosowany był też arsen jako środek do ochrony roślin, który również został przebadany przez naukowców. Udowodniono, że długotrwała ekspozycja na ten pierwiastek także przyczynia się do nowotworzenia u człowieka. Rzeszutek i wsp. [4] wykazali, że arsen podawany myszom w wodzie pitnej przez 48 tygodni wywołał u nich hipometylację DNA, o której już wcześniej było wspomniane, iż ma swój udział w procesach rakotwórczych. Podobnie było w przypadku testów z diazinonem - środkiem insektobójczym. Tym razem jednak badania przeprowadzano na materiale ludzkim. Były to wyizolowane komórki człowieka z przewlekłą białaczką szpikową. Poddając je działaniu tego pestycydu, zaobserwowano aż 918 przypadków hipermetylacji i 66 przypadków hipometylacji wysp CpG w 984 genach w porównaniu z grupą kontrolną, co dowodzi, że diazinon ma niewątpliwie wysoki wpływ na postępowanie nowotworu u człowieka [4]. Oddziaływanie pestycydów zaburza także modyfikację histonów, które biorą udział w tworzeniu chromatyny, uznawanej za przekaźnik pamięci epigenetycznej, oraz na zmianę profilu ekspresji miRNA, których zadaniem jest regulacja ekspresji genów. Wszystkie te zmiany mają znaczący wpływ na zapadalność oraz rozwój nowotworów u ludzi, czego również dowodzą opisane wcześniej badania. W tabeli 1 przedstawiono wykaz substancji wykorzystywanych w rolnictwie jako środki ochrony roślin, które powodują modyfikacje w genach oraz mają wpływ na wyższą zapadalność na dany nowotwór [4, 7].

TABELA 1. Wykaz pestycydów wpływających na rodzaj modyfikacji epigenetycznej oraz rozwój danego nowotworu [7]

\begin{tabular}{|c|c|c|}
\hline Pestycyd & Rodzaj modyfikacji & Nowotwór \\
\hline $\begin{array}{l}\text { Arsen, DDT, } \\
\text { Metoksychlor, } \\
\text { Permetryna, TCCD }\end{array}$ & $\begin{array}{l}\text { zmiany metylacji } \\
\text { DNA }\end{array}$ & $\begin{array}{l}\text { mózgu, jajników, } \\
\text { szyjki macicy, nerek, } \\
\text { wątroby, płuc }\end{array}$ \\
\hline $\begin{array}{l}\text { Dieldryna, Parakwat, } \\
\text { Propoksur }\end{array}$ & $\begin{array}{l}\text { modyfikacja } \\
\text { histonów }\end{array}$ & białaczka \\
\hline $\begin{array}{l}\text { Dichlorvus, Fipronil, } \\
\text { Furgicydy }\end{array}$ & $\begin{array}{l}\text { zmiana profilu } \\
\text { ekspresji miRNA }\end{array}$ & prostaty \\
\hline
\end{tabular}

Kwiatkowska i wsp. [8] donoszą o kontrowersji w sprawie dopuszczonego na rynek herbicydu - glifosatu; w 2002 r. urzędnicy EU stwierdzili, że nie jest on genotoksyczny. Jednak wiele badań na świecie zaprzecza temu twierdzeniu, choć większość jest przeprowadzana na preparatach, które zawierają również inne substancje chemiczne, przez co nie można jednomyślnie stwierdzić, że glifosat jest faktycznie genotoksyczny. Na północy Ekwadoru wykonano badanie obejmujące uszkodzenia DNA na dwóch grupach - pierwsza z nich to osoby mieszkające w rejonach pól uprawnych, na których stosuje się preparat Roundup, zawierający właśnie glifosat. Druga zaś była grupą kontrolną - bez żadnego bezpośredniego kontaktu z tym pestycydem [8]. Wykazano, że większy stosunek uszkodzeń DNA występuje u osób narażonych na działanie preparatów herbicydowych [8]. Z kolei w badaniach opisanych przez Kwiatkowską i wsp. [8] analizowano komórki nabłonka ludzkiego pochodzącego z ust. Wystawiono je na działanie preparatu Roundup Ultra Max, gdzie początkowe stężenie glifosatu wynosi $450 \mathrm{~g} / \mathrm{L}$, a znaczące zmiany można było zauważyć już przy stężeniu $0,01 \mathrm{~g} / \mathrm{L}$ w czasie trwania 20 min inkubacji. Badanie to potwierdza, że glifosat może być potencjalnym sprawcą w procesie nowotworzenia. Greenpeace przytacza jeszcze jedno istotne badanie na temat uszkodzeń DNA i związanej z tym zwiększonej podatności na zachorowania na nowotwory. Naukowcy 
twierdzą, że niektórzy ludzie są bardziej podatni na wpływ pestycydów z powodu konkretnej zmiany, która zachodzi w ich genach [8]. Wyniki przedstawiane przez Greenpeace [5] dowodzą, że osoby mające konkretny wariant genu GST (znany jako GSTP1 IIIe-IIIe) były bardziej narażone na uszkodzenie DNA, szczególnie jeśli znajdowały się w grupie najbardziej narażonej na kontakt z pestycydami.

Warto jeszcze wspomnieć o wpływie pestycydów na powstawanie rzadkich nowotworów. Według opinii Greenpeace jedną z głównych przyczyn zwiększonego ryzyka zachorowalności na szpiczaki mnogie, mięsaka kości i mięsaka Edwinga jest właśnie narażenie człowieka na długotrwały kontakt z pestycydami niż na inne substancje chemiczne. Wykazano też, że u osób pracujących z pestycydami chloroorganicznymi i fosforoorganicznymi zauważa się wzrostową tendencję zapadalności na rzadką odmianę białaczki - włochatokomórkowej [5].

\section{EFEKTY KONTAKTU PESTYCYDÓW W OKRESIE PŁODOWYM I NIEMOWLĘCYM}

Kobiety w ciąży oraz niemowlęta są grupą, którą powinno się obejmować szczególną opieką w każdej dziedzinie. Najlepszym rozwiązaniem w tym przypadku jest całkowita eliminacja środków ochrony roślin z życia kobiety ciężarnej oraz mamy i jej dziecka. Jednak obecnie nie jest to możliwe. Można jedynie ograniczyć ten kontakt do minimum [9]. W okresie płodowym styczność z pestycydami może mieć poważne konsekwencje w przyszłości. Mózg rozwijającego się płodu jest bardziej podatny na wpływ neurotoksyn, a stężenie pestycydów jest dużo wyższe niż u osoby dorosłej ze względu na małe rozmiary nienarodzonego dziecka [5]. Układ odpornościowy jest dopiero w trakcie kształtowania się, przez co gorzej radzi sobie ze zwalczaniem toksycznych związków [9], odznacza się niską aktywnością enzymów rozkładających pestycydy, a to z kolei prowadzi do obniżonej detoksykacji oraz zmniejszonego wydalania z organizmu [5]. Pestycydy mogą również zaburzać pracę układu hormonalnego dziecka, który nie jest jeszcze w pełni rozwinięty [6]. Badania wykonane na zwierzętach sugerują, że narażenie na działanie PCB, heksachlorobenzen, DDT oraz produkt rozkładu DDE w okresie prenatalnym może mieć szkodliwy wpływ na rozwój neurologiczny [10]. Według Sobczaka [9] narażenie na środowiskowe substancje chemiczne jest szczególnie niebezpieczne dla zdrowia płodu w okresie, gdy jego narządy znajdują się w czasie oznaczonym jako „okno wrażliwości”. Autor ten przytoczył także badania, z których wynika, że we krwi pępowinowej noworodków wykryto wiele substancji chemicznych, w tym pestycydy chloroorganiczne. Na szukanych 28 związków wykryto aż 21 różnych pestycydów z klasy chloroorganicznych [9]. Poradnik PAN Europe [6] donosi, że zakłócenie pracy hormonów może prowadzić do niewłaściwej budowy mózgu, nerwów, podatności na choroby nowotworowe. Zaburzenia te mogą zostać niezauważone w pierwszych latach życia dziecka, a skutki mogą pojawić się dopiero w przyszłości, np. ADHD, nieprawidłowości w układzie motoryki, kłopoty z pamięcią czy ryzyko wystąpienia niepłodności.
Potwierdza to przypadek „córek DES”. W latach 50. XX w. podawano kobietom w ciąży substancję chemiczną o nazwie dietylostilbestrol (DES), który miał zmniejszyć ryzyko zgonu dziecka podczas ciąży i porodu. Jednak skutki jego podawania były zupełnie inne. Dietylostilbestrol wywoływał szereg zaburzeń gospodarki hormonalnej, czego następstwami były przypadłości wykryte dopiero po wielu latach, kiedy to dzieci matek przyjmujących DES podczas ciąży były już dorosłe. Głównie dotknęło to kobiet. Konsekwencjami była m.in.: niepłodność, powikłania ciąży, nowotwór pochwy czy zwiększone ryzyko zachorowania na raka piersi [6]. Rzeszutek i wsp. [4] opisali doświadczenie wykonane na szczurzych zarodkach potwierdzające, że narażenie płodu na kontakt z pestycydami niesie za sobą poważne implikacje w okresie dorosłości. Proces metylacji DNA wywołany działaniem winklozoliny spowodował u dorosłych szczurów wady narządów płciowych. Doszło do modyfikacji komórek prekursorowych plemników, które wpłynęły na spermatogenezę, a także utrzymywały się przez następne pokolenia. Udowodniono też, że najbardziej podatnym gatunkiem na działanie winklozoliny są ssaki, zwłaszcza w okresie płodowym, kiedy wyodrębnia się płeć [4]. Przytoczone przez Żak [7] badania potwierdzają, że metosychlor, jeden ze składników środków owadobójczych, wpływał negatywnie na przebieg ciąży, procesy rozrodcze oraz rozwój jąder u samców. Małe dzieci są tak samo narażone na konsekwencje kontaktu z pestycydami jak te nienarodzone. Dzieci poniżej 3. r.ż. są najbardziej narażone na kontakt z pestycydami przez połknięcie lub wdychanie pyłów z gleby i kurzu oraz poprzez dietę i powietrze [5]. Badania przeprowadzone w USA na grupie dzieci w wieku przedszkolnym dowiodły, że mimo narażenia na kontakt z pestycydami drogą różnych źródeł, tj. czynniki środowiskowe (gleba, kurz) czy przedmioty osobiste, głównym źródłem narażenia na pestycydy - chloropiryfos i permetrynę - była jednak żywność. Greenpeace [5], powołując się na 27 publikacji badawczych, stwierdza, że wyżej wymienione czynniki mają niekorzystne działanie na procesy poznawcze i behawioralne u dziecka związane z zaburzeniami rozwojowymi mózgu. Są one wywołane stycznością z pestycydami fosforoorganicznymi, zwłaszcza gdy takie dziecko ma osłabioną zdolność ruchową. Naukowcy dokonali analizy budowy mózgu, wykonując obrazowy rezonans magnetyczny na 40 pacjentach w przedziale wiekowym 6-11 lat. Udowodniono, że z powodu ekspozycji matek na chloropiryfos w okresie ciąży ich dzieci miały widoczne zmiany w strukturze mózgu, patologiczne przerosty w pewnych rejonach, zaś w innych ubytki [5]. Według Greenpeace [5] badania te sugerują, że wspomniane efekty neurotoksyczne są długofalowe i obejmują cały okres dzieciństwa. Pesticide Action Network Europe [6] sugerował, że toksyczność pestycydów wpływa również na zwiększone ryzyko wystąpienia ADHD u dzieci [6]. Tezę tę potwierdza Greenpeace [5], przytaczając pracę, w której badano osoby w wieku 8-15 lat mające kontakt z pestycydami fosforoorganicznymi, głównie poprzez żywność. Stwierdzono, że u tych dzieci zdecydowanie częściej rozpoznawano to schorzenie [5].

Jeśli chodzi o zwiększone ryzyko wystąpienia wad wrodzonych u dzieci, których matki były narażone bezpośrednio 
na kontakt z pestycydami poprzez pracę $\mathrm{w}$ rolnictwie, lub nawet u dzieci, których rodzice często korzystali ze środków ochrony roślin, to jest ten temat dosyć dobrze opisany i można przy toczyć wiele badań. Jurewicz i Handke [11] opisali kilka takich przypadków. W Bogocie zaobserwowano widoczny wzrost ryzyka urodzeń dzieci z naczyniakiem krwionośnym u kobiet pracujących na plantacjach kwiatów w zamkniętych tunelach foliowych. Podobną zależność zauważono na Filipinach. U dzieci urodzonych w rodzinach, gdzie ojciec był farmerem i przygotowywał roztwory pestycydów lub sam przeprowadzał opryski upraw, zanotowano podwyższone zagrożenie wystąpienia wad wrodzonych [11]. Analiza wad wrodzonych u 261 niemowląt prowadzona w Hiszpanii wykazała, iż w przypadku, gdy matki pracowały w rolnictwie w okresie jednego miesiąca przed zapłodnieniem i w pierwszym trymestrze ciąży, iloraz szans wystąpienia wady wrodzonej był istotnie zwiększony. Najczęstszymi diagnozowanymi wadami były wady złożone i podniebienia oraz uszkodzenia układu nerwowego [11]. Greenpeace [5] nawiązuje jeszcze do zależności między narażeniem płodu na pestycydy a białaczką. Na podstawie badań można wywnioskować, iż jeśli kobiety ciężarne mają styczność z pestycydami (podczas pracy zawodowej lub stosują je w domowym ogródku), istnieje podwyższone ryzyko zachorowania u ich dzieci na ten typ nowotworu [5].

Jeśli chodzi o wpływ pestycydów na poronienia i przedwczesne porody, to są na ten temat różne badania, które nie wskazują jednoznacznie, że te związki są bezpośrednim sprawcą. Pestycydy chloroorganiczne mają strukturę, która jest rozpuszczalna w tłuszczach, przez co mogą zakłócać harmonię między dwoma ważnymi hormonami w czasie ciąży - estrogenem i progesteronem. Wyizolowane z krwi pępowinowej związki pestycydowe $\beta$-HCH i $\gamma$-HCH mogą wskazywać, iż jest to powiązane ze zwiększonym odsetkiem poronień nawykowych. Greenpeace [5] opisuje holenderskie kobiety pracujące w szklarniach z kwiatami, gdzie rutynowo stosuje się duże ilości abamektyny, metiokarbu, deltametryny i pirymikrabu. Ryzyko poronienia wśród omawianych kobiet wzrastało 4-krotnie [5]. Oddziaływanie pestycydów w okresie prenatalnym może też wpływać na rozwój chorób tarczycy. Poprzez działanie neuroleptyczne zaburzają one pracę gospodarki hormonalnej tarczycy, która jest potrzebna do prawidłowego przebiegu procesu rozwijania się mózgu u ssaków. Niedostateczna ilość jodu w okresie płodowym prowadzi do niedoczynności tarczycy, a ta z kolei do matołectwa. Przedstawione badania udowadniają, iż niski poziom tyroksyny $(<10 \%)$ u kobiet w czasie ciąży ma związek z rozwojem umysłowym u dzieci między 10. miesiącem a 8. r.ż. [10].

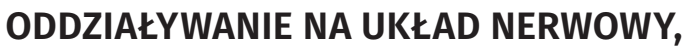 HORMONALNY ORAZ IMMUNOLOGICZNY}

Znaczna ilość pestycydów, głównie tych zwalczających szkodniki, została stworzona z zamysłem działania neurotoksycznego dla insektów. Zatem jest możliwość, że będą też niekorzystnie wpływać na układ nerwowy człowieka, przez co mogą powodować szereg długofalowych nieprawidłowości w organizmie [5]. Grosicka-Maciąg [12] stwierdza, że objawy charakterystyczne dla choroby Parkinsona (PD) zaobserwowano u ludzi stale narażonych na działanie pestycydów z grupy ditiokarbaminianów, szczególnie na maneb [12]. Ma on wpływ na patologiczne zmiany zachodzące w mitochondriach, mianowicie rozrywa łańcuch oddechowy. Zakłócenie tej frakcji wpływa na powstawanie wolnych rodników w organizmie. Według przytoczonych badań, wykonanych po śmierci, mózg osoby chorującej na PD przejawiał znaczące modyfikacje w cechach stresu oksydacyjnego [12]. Sińczuk-Walczak [13] skupiła się na konkretnym związku i jego wykorzystaniu w rolnictwie arsenie. Osoby zatrudnione przy pracy z pestycydami należą do grupy szczególnie narażonej na konsekwencje związane z ekspozycją na ten konkretny pestycyd. Arsen wchłania się dwoma kluczowymi drogami - wziewnie, poprzez wdychanie nieorganicznych cząsteczek oraz przez przewód pokarmowy, w wyniku spożycia żywności lub wody pitnej skażonej pozostałościami. Sińczuk-Walczak [13] przytacza także badania z lat 50. XX w., w których opisano 41 przypadków chorób układu nerwowego wywołanych narażeniem na arsen w USA, z których 7 spowodowanych było zawodowym narażeniem podczas oprysków pestycydami [13]. Z kolei dzięki obserwacjom japońskich naukowców wywnioskowano, że kontakt zawodowy z arsenem przyczynia się do występowania polineuropatii czuciowo-ruchowej oraz zwiększonej zapadalności na pozagałkowe zapalenie nerwu wzrokowego [11]. Niekorzystny wpływ na układ nerwowy mają też takie pestycydy jak parakwat, propoksur czy dieldryna. Ingerując w modyfikację histonów, powodowały kumulację pozostałości w centralnym układzie nerwowym [7]. W konsekwencji wywoływany stres oksydacyjny powoduje apoptozę neuronów, a także degenerację, zwłaszcza komórek produkujących dopaminę, związanych szczególnie z chorobą Parkinsona [4]. Greenpeace [5] wymienia parakwat jako substancję 2-krotnie zwiększającą ryzyko zapadalności na PD. Według Piechowicz i wsp. [14] zakłócenia w tym układzie najczęściej prowadzą do zachorowalności na PD, z objawami takimi jak: depresja, niepokój, znużenie, zaburzenie funkcjonowania szlaków dopaminergicznych. Takie symptomy zaobserwowano u osób narażonych na działanie pestycydów. Obserwuje się również zaburzenia pamięci, dysfunkcję sensomotoryki lub opóźnienie czynności percepcjo-ruchowych - te z kolei przypominają objawy choroby Alzheimera lub demencji [14]. Greenpeace [5] również sugeruje, że kontakt ze środkami ochrony roślin zwiększa ryzyko zachorowalności na PD, szczególnie jeśli są to pestycydy z grupy herbicydów bądź insektycydów. Przytoczone badania potwierdzają tę tezę. We krwi ludności zamieszkującej północne tereny Indii stwierdzono podwyższone parametry $\beta$-HCH i dieldrinu, które przyczyniają się do rozwoju PD [5]. Jeśli chodzi o predyspozycje genetyczne i związaną z tym zwiększoną podatność zachorowania na PD, to jest podobnie jak w przypadku nowotworów. W przytoczonych przez Greenpeace [5] badaniach wykonanych na rolnikach w południowo-wschodnim Tajwanie wyodrębniono dwa warianty genów - MnSOD i NQO1, które podwyższają zagrożenie zapadalności 
na chorobę Parkinsona w porównaniu z osobami nieposiadającymi tych wariantów genowych. Geny produkują źle funkcjonujące enzymy, przez co potęgują możliwość powstawania defektów w tkance mózgu, czego konsekwencją jest aż 4-krotny wzrost ryzyka zachorowania na PD. Inny autor opisuje, że za uszkodzenia mózgu odpowiedzialny jest również gen GSTP-1, który zamiast odtruwać organizm z pestycydów, podwyższa ich toksyczność w organizmie [5]. Dobrowolska [15] przytacza przypadek narkomanów z lat 80. XX w., u których po wstrzyknięciu heroiny zanieczyszczonej MPTP wystąpiły nieodwracalne objawy choroby Parkinsona. Przyczyną toksycznego efektu była inhibicja przez MPTP enzymów mitochondrialnych. Pestycyd roteton hamuje aktywność tego samego enzymu mitochondrialnego - kompleksu I, co MPTP. Na podstawie tych zależności wysunięto hipotezę zakładającą, że długotrwałe podawanie szczurom rotetonu w niskich dawkach mogłoby wywoływać PD. Podawano go dożylnie przez kilka tygodni i zaobserwowano postępującą degradację neuronów dopaminowych, które są jednym z objawów rozpoznania PD. Można też było zaobserwować formowanie się struktur przypominających ciałka Lewy'ego, które są związane z występowaniem choroby Alzheimera [15]. Szereg prac wskazuje na istotne powiązanie między zachorowalnością na Alzheimera lub wystąpieniem otępienia naczyniopochodnego (rodzaj demencji) a narażeniem na konkretne pestycydy, zwłaszcza fosforoorganiczne. Jak było w przypadku choroby Parkinsona, zwiększona podatność może być spowodowana genami, najpewniej z przyczyn zachodzących zmian w enzymach odtruwających i kodujących ich genach [5].

Kolejnym omawianym wątkiem jest oddziaływanie pestycydów na układ hormonalny człowieka. Kwiatkowska i wsp. [8] przytaczają wyniki badań, w których wspominany już glifosat, a konkretnie preparaty go zawierające, może działać jak modulatory hormonalne i przez to przyczyniać się do zaburzeń układu wewnątrzwydzielniczego. W badaniach na szczurach, którym podawano preparat zawierający glifosat w okresie dojrzewania, zaobserwowano widoczne nieprawidłowości w stężeniu testosteronu. Czas dojrzewania znacząco się wydłużył, a także zauważono przerost organów wewnętrznych. Z kolei w innych badaniach dowiedziono, że poprzez spowalnianie aktywności aromatazy preparaty z glifosatem mają działanie przekształcające androgeny do estrogenów, ale również mogą obniżać poziom testosteronu oraz estradiolu, który bierze udział w określaniu płci i wpływa na zachowanie płciowe dojrzałego organizmu [8].

Do zaburzeń hormonalnych spowodowanych pestycydami można również zaliczyć choroby tarczycy, na które zapada coraz więcej ludzi. Niektóre ze środków ochrony roślin, głównie chwastobójcze, przeciwgrzybicze lub najczęściej stosowane - owadobójcze, mają negatywny wpływ na hormony tarczycy poprzez zahamowanie wchłaniania jodu czy oddziaływanie na receptory tarczycowe. Badania na zwierzętach potwierdzają, że popularny DDT oraz amitrol mają działanie goitrogenne i mogą wpływać na spadek hormonów FT3 i FT4, jak również podwyższać poziom TSH, czyli dawać jawne objawy zaburzenia tarczycy [16]. Jak piszą Goldner i wsp. [16], w badaniach na osobach pracujących ze środkami owadobójczymi i chwastobójczymi w River Valley (płn.-zach. Minnesota, USA) stwierdzono wyższy stopień zaburzenia hormonów TSH - o 3,4\% w porównaniu z 1\% całej populacji [16]. Badania przeprowadzone w Danii u osób pracujących w szklarniach wykazały wzrost hormonu tyreotropowego aż o 32\%, zaś jeśli chodzi o ft3 i ft4, były to niższe wartości - 5-9\%, jednak także podwyższone. Według Goldner i wsp. [16] pracownicy szklarni byli narażeni na działanie aż 60 różnych chemikaliów, w tym m.in. pirymikarb, benomyl, iprodion, chlormekwat oraz daminozyd [16]. Autorzy wyników badań sugerują, że żony rolników, które pracowały przy opryskach, ale także i kobiety zamieszkujące lub pracujące na polach uprawnych, były bardziej narażone na zapadalność na choroby tarczycy w stosunku do ogółu populacji. Ta zwiększona tendencja została połączona z ekspozycją na insektycydy chloroorganiczne, fungicydy, tj. benomyl, a także karbaminiany (maneb i mankozeb) [5]. W Brazylii na terenach silnie skażonych pestycydami chloroorganicznymi wykazano, że w populacji 608 dorosłych osób (303 mężczyzn i 305 kobiet) występowała zwiększona zachorowalność na nadczynność tarczycy. Zauważono także, że u kobiet obserwowano podwyższony poziom hormonów tarczycy, z kolei u mężczyzn - niski [5].

Toksyczne oddziaływanie pestycydów zostawia również ślad w układzie immunologicznym. Pyszel i wsp. [17] stwierdzili, iż ditiokarbaminiany mają wpływ na czynnik transkrypcyjny NF-kappaB, którego aktywację wiąże się z ekspresją wielu genów, szczególnie tych odgrywających rolę w immunogenności i reakcjach zapalnych. Zahamowanie tego czynnika w makrofagach prowadzi do zmniejszonej syntezy tlenku azotu, który jest ważnym regulatorem w odpowiedzi immunologicznej [17]. Z kolei Greenpeace przytacza po raz kolejny badania, w których odnotowano, że u rolników pracujących ze środkami ochrony roślin istnieje 2-krotnie wyższe ryzyko zachorowania na astmę. Szczególnie jeśli te osoby miały kontakt z preparatami zawierającymi kumafos, bromek etylenu, heptachlor, paration. Inne badania sugerują, że pestycydy takie jak diazinon, glifosat, malation lub permetyna mogą być odpowiedzialne za zwiększone występowanie alergicznego nieżytu nosa u osób pracujących na plantacjach [5].

\section{WPŁYW PESTYCYDÓW NA ROZRODCZOŚĆ}

Na przełomie lat 1960-2001 zaobserwowano w krajach rozwiniętych znaczący wzrost niepłodności (o 50-60\%), której jednym z powodów jest zwiększone zanieczyszczenie ekosystemu. Najczęstszymi związkami skażającymi środowisko są pestycydy fosforoorganiczne i karbaminiany. W przytoczonych przez Grosicką-Maciąg [12] wynikach badań prowadzonych na szczurach wykazano, że wprowadzenie do żywego organizmu pestycydów (zimeb, dimetoad, glifosat) wpływa na podwyższenie stężenia parametrów stresu oksydacyjnego w jądrach oraz na działanie hormonów skonsolidowanych ze zdolnościami prokreacji. Ryzyko wzrastało, gdy obiekty doświadczalne były wystawione na ekspozycję więcej niż 
jednego pestycydu. Z danych wynika, że skutki bezpłodności wywołane stałym kontaktem ze środkami ochrony roślin częściej dotykają mężczyzn niż kobiet. Może to wynikać z tego, że dokładne przyczyny występowania bezdzietności u kobiet nie są do końca poznane [12]. Grosicka-Maciąg [12] stwierdza, że ekspozycja kobiet na pestycydy powoduje zaburzenia cyklu owulacyjnego na różnym etapie. Kwiatkowska i wsp. [8] przeprowadzili badania na samcach szczurów, wystawiając je na działanie herbicydu, co może być przyczyną nieprawidłowości w przebiegu spermatogenezy, a w konsekwencji przyczyniać się do bezpłodności [8].

\section{ZWIACZZK PESTYCYDÓW Z ZAPADALNOŚCIĄ NA CUKRZYCE}

Z analizowanego piśmiennictwa wynika, że ekspozycja na pestycydy fosforoorganiczne (poprzez zanieczyszczoną żywność) powoduje uszkodzenie trzustki oraz jest jedną z przyczyn zwiększonej zachorowalności na cukrzycę. Z przeglądu danych wynika, że u osób narażonych na ich oddziaływanie obserwuje się okresowe wzrosty glukozy we krwi oraz glikozurię, a także hiperlipidemię i hiperinsulinemię. Z kolei w badaniach przeprowadzonych w Australii zauważono podwyższone ryzyko występowania cukrzycy ciążowej u żon rolników pracujących z pestycydami fosforoorganicznymi [18]. Łukasiewicz-Hussain [18] przytacza badania wykonane na szczurach, którym podawano dimetoat w dawce $20 \mathrm{mg} / \mathrm{kg}$ m.c. i $40 \mathrm{mg} / \mathrm{kg}$ m.c. przez okres 30 dni. Zaobserwowano wzrost aktywności lipazy oraz amylazy w surowicy z jednoczesnym obniżeniem aktywności tych enzymów w trzustce. U szczurów dostających wyższą dawkę zauważono spadek masy ciała, ale również powiększenie się narządu [18].

Wpływ na rozwój cukrzycy ma również arsen, wspominany już w kontekście nowotworów, jak i zaburzeń układu nerwowego. Z przeprowadzonych badań na zwierzętach oraz hodowlach komórkowych wynika, że arsen może mieć wpływ na mechanizmy przyczyniające się do zapadalności na cukrzycę. Posiada on podobne właściwości biochemiczne jak fosfor, zatem może „wskoczyć” na jego miejsce w reakcji powstawania ATP [19]. Marchewka i Grzebinoga [19] podają, że w rezultacie takiej podmiany powstaje arsenian adenozynodifosforanu, co skutkuje nieprawidłowym wytwarzaniem energii i zahamowaniem szlaków metabolicznych wymagających ATP jako źródła energii [19]. Może także wbudowywać się w reakcję powstawania glukozo-6-fosforanu, przez co powstaje glukozo-6-arsenian, który może zaburzać metabolizm glukozy. Pierwsze odnotowane przypadki powiązania arsenu i cukrzycy zauważono w populacji tajwańskiej. Zaobserwowano, że u Tajwańczyków mających kontakt z dużą dawką arsenu poprzez zanieczyszczoną wodę pitną ryzyko wystąpienia cukrzycy było 2-krotnie większe w porównaniu z ogółem ludności. W badaniach przeprowadzonych przez Marchewkę i Grzebinogę [19] stwierdzono, że zachorowania na cukrzycę w wioskach, w których było duże narażenie na arsen, wynosiło
27,4 na 1000 osób, podczas gdy w nieendemicznych miastach mieściło się w granicach 19 osób na 1000.

\section{ZATRUCIA PESTYCYDAMI}

Szereg publikacji naukowych przytacza różnorodne przypadki zatruć pestycydami, spowodowanych pomyłką, niedopatrzeniem, nieprzestrzeganiem procedur związanych z wykonywaniem oprysku lub będących wypadkiem przy pracy [8]. Według Kwiatkowskiej i wsp. [8] każdego roku na świecie odnotowuje się ok. 3 mln zatruć pestycydami, z czego 220 tys. śmiertelnych. W samej Polsce w 2000 r. odnotowano 107 przypadków zatruć. Dane te dowodzą, że ocenianie ryzyka u osób pracujących ze środkami ochrony roślin musi być obowiązkowe, ponieważ jest to nieodzowna część przebiegu analizy toksykologicznej [8]. Thundiyil i wsp. [20] stwierdzili, że użycie pestycydów zakazanych w krajach uprzemysłowionych, w szczególności toksycznych, wskazanych przez WHO, przeterminowanych środków oraz przechowywanych w złych warunkach prowadzi do zwiększenia wskaźnika zatruć. W krajach takich jak Chiny czy Sri Lanka samozatrucie pestycydami jest znacznym problemem. Badania na Sri Lance wskazują, że ostre zatrucie pestycydami dotyczy ok. 180 na 100 tys. osób [20]. Jak oceniają Kwiatkowka i wsp. [8], w odnotowanych przypadkach zatruć glifosatem stężenie we krwi osób badanych wynosiło średnio $61 \mathrm{mg} / \mathrm{dL}$, co oznacza łagodne zatrucie, natomiast nawet do $4146 \mathrm{mg} / \mathrm{dL}$ to dawka doprowadzająca do zgonu. Objawy kliniczne zatrucia tym herbicydem to głównie niewydolność oddechowa i zakłócenia rytmu serca [8]. Zatrucia jakimkolwiek pestycydem niosą za sobą nieodwracalne uszkodzenia w organizmie. Zarówno ciągła ekspozycja w małych dawkach, jak i jednorazowa duża dawka ma niepożądane konsekwencje zdrowotne.

\section{BIOPESTYCYDY - LEPSZA ALTERNATYWA?}

Warto zwrócić uwagę na substancje, które mogą być rozwiązaniem problemu szkodliwego działania pestycydów na organizm i mogą niwelować utrudnienia związane z ich używaniem. Pierwsza omawiana substancja to spinosad, który jest prokurentem pestycydów nowej generacji - biopestycydów będących naturalnym produktem. W 1982 r. na Karaibach odkryto bakterię Saccharopolyspora spinosa, która po zbadaniu przejawiała cechy owadobójcze. Sikorska i Wędzisz [1] stwierdziły, że w wyniku fermentacji Saccharopolyspora spinosa i pozyskiwania flory bakteryjnej z organizmów zasiedlających glebę uzyskuje się właśnie spinosad [1]. Jego działanie opiera się na zastoju w kanałach chlorkowych, co jest równoznaczne z zatrzymaniem przebiegu przepływu jonów chloru, czego końcowym rezultatem jest paraliż szkodnika [21]. Wśród wielu właściwości jedną z głównych zalet jest krótki okres półtrwania tej substancji w środowisku, mieszczący się w przedziale niespełna 2-17 dni [1]. Według Sikorskiej i Wędzisz [1] 10-miesięczne testy badające degradację spinosadu w glebie 
do głębokości 60,96 cm wykazały brak śladów obecności metabolitów tego związku w glebie. Kolejną zaletą jest działanie tylko i wyłącznie na owady oraz bardzo dobra skuteczność w niskich dawkach. Przeprowadzone badania w Kalifornii, gdzie uży to spinosadu do ochrony plantacji jabłoni, wykazały istotnie niższy odsetek larw szkodników [1]. Z kolei badania wykonywane na zwierzętach, którym podawano różne dawki spinosadu (mysz - 4,98 mg/kg/d, kot - 8,60 mg/kg/d, pies 6,00 mg/kg/d), wykazały brak właściwości rakotwórczych, co oznacza, że jest wyjątkowo słabo toksyczny dla ssaków. Opierając się na danych EPA, ustalono, że dawka bezpieczna dla człowieka, czyli niewywołująca żadnych efektów patologicznych, wynosi 0,0268 mg/kg/d. Jak do tej pory bazy Medline i Toxline nie zawierają publikacji opisujących przypadki zatruć spinosadem. Na świecie jest on zarejestrowany w 58 krajach i dopuszczony do stosowania. Jednak pomimo wielu zalet w Polsce jest on uznawany za substancję niebezpieczną i wymagane jest oznakowanie jego obecności w opakowaniach jednostkowych [1]. Innym biopestycydem jest abamektyna, która również jest pozyskiwana w wyniku fermentacji z bakterii glebowej Streptomyces avermitilis i należy do makrocyklicznych laktonów, podobnie jak i spinosad. Sadowska-Rociek i Cieślik [21] opisały ją jako mieszaninę dwóch homologów zawierających więcej niż 80\% awermektyny B1a i mniej niż 20\% awermektyny B1b [21]. Ma właściwości owadobójcze i roztoczobójcze. Działa podobne jak spinosad - hamuje przepływ w kanałach chlorkowych. Azadyrachtyna pozyskiwana jest z rośliny Azadirachta indicta (miodla indyjska). Oprócz naturalnych cech insektobójczych wykazuje także działanie hamujące potencjał rozrodczy owadów. Ten biopestycyd ma także inny niż poprzednie kierunek działania - uszkadza chromosomy oraz zaburza przebieg mitozy w organizmie owada [21]. Opisano przypadek, w którym abamektyna jako jedna z substancji mogła być związana ze zwiększonym ryzykiem poronień kobiet pracujących w rolnictwie [5].

W grupie biopestycydów wyróżnia się także produkty posiadające jako substancje czynne feromony lub inne związki chemiczne emitowane przez zwierzęta i rośliny („semiochemicals”) oraz mikroorganizmy lub często od lat bezpiecznie stosowane ekstrakty roślinne [22].

Jak podkreślają źródła literaturowe, wszystkie wymienione substancje są bezpieczne dla zdrowia człowieka i jak do tej pory nie odnotowano żadnych skutków ubocznych ich stosowania $[1,21]$.

\section{PODSUMOWANIE}

Reasumując, nie ma bezpośrednich dowodów, że konkretna choroba czy schorzenie są spowodowane tylko przez styczność z konkretnym pestycydem. Żak [7] stwierdza, że w całej populacji ludzkiej nie da się znaleźć grupy ludzi, która nigdy nie zetknęła się z pestycydami. Na każde schorzenie lub przypadłość składa się wiele innych czynników zarówno środowiskowych, jak i genetycznych, mogących wpływać na to, co się stanie, dlatego tak trudno określić jednoznaczną przyczynę zapadania na choroby spowodowane przez pestycydy [7]. Wyróżniono gen GSTP-1 jako potencjalny czynnik rozwoju zarówno nowotworów, jak i przyczynę uszkodzeń układu nerwowego, czego konsekwencją jest zwiększona zapadalność na chorobę Parkinsona [5]. Opisane zostały m.in. działania pestycydów na okres płodowy, oddziaływanie na małe dzieci oraz na rolników, osoby pracujące w ogrodnictwie lub na plantacjach [5]. Powodują one szereg zaburzeń w organizmie, są przyczyną wad rozwojowych u dzieci, zaś u pracowników ogrodniczych wpływają na rozwijanie się bezpłodności, zwiększonej zachorowalności na cukrzycę czy występowanie zaburzeń hormonalnych [8, 12, 18, 19]. Zatem należałoby dla tych grup ograniczyć kontakt z pestycydami do minimum lub znaleźć alternatywne rozwiązanie, dzięki któremu nie będą eksponowane na działanie środków ochrony roślin [5]. Mówiąc o alternatywach, być może preparaty takie jak spinosad, abamektyna czy azadyrachtyna są dobrym rozwiązaniem problemu toksyczności pestycydów. Z przytoczonych badań wynika, że są po pierwsze naturalnie pozyskiwanymi środkami, po drugie - działają tylko i wyłącznie na organizm szkodnika [1,21]. Jeśli chodzi o zatrucia, to ich przyczyną jest bardziej ludzki błąd, niewiedza, jak używać pestycydu lub niedopatrzenie podczas wykonywania oprysku - nieodpowiednie ubranie ochronne, uszkodzony sprzęt lub brak wiedzy, jak wykonywać oprysk. Same zatrucia w wyniku spożycia żywności czy ekspozycji z powodu zanieczyszczenia środowiska nie zostały odnotowane $[8,13,20]$.

\section{PIŚMIENNICTWO}

1. Sikorska K, Wędzisz A. Nowoczesne pestycydy - spinosad. Bromat Chem Toksykol 2009;42(2):203-12.

2. Dobosz B, Jaskólecki H. Pozostałości pestycydów w żywności pochodzenia roślinnego. Problemy Ekologii 2007;11(4):187-90.

3. Wrzosek J, Gworek B, Maciaszek D. Środki ochrony roślin w aspekcie ochrony środowiska. Ochrona Środowiska i Zasobów Naturalnych 2009;39:75-88.

4. Rzeszutek J, Popek S, Matysiak M, Czajka M, Sawicki K, Kruszewski M, et al. Zmiany epigenetyczne spowodowane ekspozycją na pestycydy. Probl Hig Epidemiol 2014;95(3):561-7.

5. Negatywny wpływ pestycydów na zdrowie - rosnący problem. Rasearch Laboratories. Greenpeace; 2015. p. 3-53. http://www.greenpeace.org/ poland/PageFiles/671146/Raport_Wplyw_pestycydow_na_zdrowie. pdf (3.03.2017).

6. Niebezpieczna żywność. Chemiczne substancje w żywności UE zaburzające gospodarkę hormonalną. Pesticide Action Network Europe; 2013. p. 1-32.

7. Żak A. Środki ochrony roślin a zmiany w środowisku naturalnym i ich wpływ na zdrowie człowieka. Zagadnienia Ekonomiki Rolnej 2016;1(346):155-66.

8. Kwiatkowska M, Jarosiewicz P, Bukowska B. Glifosat i jego preparaty - toksyczność, narażenie zawodowe i środowiskowe. Med Pr 2013;64(5):717-29.

9. Sobczak A. Czynniki chemiczne w środowisku zagrażające zdrowiu ludzi. Med Środow 2012;15(1):7-17.

10. Chevrier J, Eskenazi B, Holland N, Brandman A, Barr D. Effects of exposure to polychlorinated biphenyls and organochlorine pesticides on thyroid function during pregnancy. Am J Epidemiol 2008;168:298-310.

11. Jurewicz J, Handke W. Zawodowa i środowiskowa ekspozycja na pestycydy a ryzyko wystąpienia wad wrodzonych - przegląd badań epidemiologicznych. Probl Hig Epidemiol 2008;89(3):302-9.

12. Grosicka-Maciąg E. Biologiczne skutki stresu oksydacyjnego wywołanego działaniem pestycydów. Post Hig Med Dosw 2011;65:357-66. 
13. Sińczuk-Walczak H. Zmiany w układzie nerwowym w następstwie narażenia zawodowego na arsen i związki nieorganiczne arsenu w świetle piśmiennictwa. Med Pr 2009;60(6):519-22.

14. Piechowicz B, Stawarczyk K, Stawarczyk M. Zagrożenia wynikające ze stosowania chemicznych środków ochrony roślin. Bezp Pr Nauk Prakt 2012;3:5-7.

15. Dobrowolska A. Odmiany roślin transgenicznych Bt a pestycydy - aspekty środowiskowe i zdrowotne. Kosmos, Problem Nauk Biologicznych 2002;51;1(254):99-104.

16. Goldner W, Sandler D, Yu F, Hoppin J, Kamel F, LeVan T. Pesticide use and thy roid disease among women in the agricultural health study. Am J Epidemiol 2010;171:455-64.

17. Pyszel A, Wróbel T, Szuba A, Andrzejak R. Wpływ narażenia na metale, benzen, pestycydy i tlenek etylenu na układ krwiotwórczy. Med Pr 2005;56(3):249-55.
18. Łukasiewicz-Hussain A. Wpływ pestycydów fosforoorganicznych na trzustkę. Med Pr 2011;62(5):543-50.

19. Marchewka Z, Grzebinoga A. Substancje chemiczne - czynnikami ryzyka nefropatii cukrzycowej. Post Hig Med Dosw 2009;63:592-7.

20. Thundiyil JG, Stober J, Besbelli N, Pronczuk J. Acute pesticide poisoning: a proposed classification tool. Bull World Health Organ 2008;86(3):205-9.

21. Sadowska-Rociek A, Cieślik E. Pestycydy nowej generacji - pozostałości w żywności, metody oznaczania i wyzwania analityczne. In: Tarko T, Duda-Chodak A, Witczak M, Najgebauer-Lejko D, editors. Technologia produkcji i bezpieczeństwo żywności. Kraków: Oddział Małopolski Polskiego Towarzystwa Technologów Żywności; 2014. p. 215-23. http:// www.pttzm.org/attachments/file/monografia__prod.pdf (11.05.2017).

22. Czaja K, Góralczyk K, Struciński P, Hernik A, Korcz W, Minorczyk M, et al. Biopesticides - towards increased consumer safety in the European Union. Pest Manag Sci 2015;71:3-6. 